\title{
Mitigation of Mount Sinabung Eruption Disaster: The Socio-Political Impact of Refugee Relocation Policy in Siosar
}

\author{
Tonny P Situmorang \\ Political Science Department \\ University of Sumatera Utara \\ Medan, Indonesia
}

\begin{abstract}
Disaster is a serious problem faced by various countries in the world. Volcanic eruptions are among the disasters that have to be tackled routinely. Mount Sinabung, located in Karo Regency in the North Sumatera Province, is one of the recent active volcanoes which last erupted in 1600 . However, it erupted again in 2010. Since 2010 until 2017 recently, the volcano has experienced its eruption routinely. In 2015, the Indonesian Government has established the Siosar region in Merek District, part of the Karo Regency, as a temporary shelter for the eruption refugees. There are 370 householders who have been evacuated to the region which is located 17 kilometers away from Kabanjahe. This study is a qualitative research with a critical paradigm to explain the phenomenon that occurs by placing interviews as primary data and books as well as international journals and national journals as secondary data. The result of this study indicates there are still many sociopolitical problems related to the relocation of Sinabung eruption in Siosar. The ownership status of the temporary shelter, the disappearance of the local wisdom of refugee communities and the welfare of the displaced people is still far from what has been promised. The study concludes with the importance of policies that take into account of socio-political aspects of the relocation.
\end{abstract}

\section{Keywords-Disaster, Mitigation, and Refugee relocation}

\section{INTRODUCTION}

Measuring the success of a region to overcome the problems in tackling the disaster is the ability of the area in pre-disaster, disaster response and post-disaster. The success is never separated with the patterns of cooperation made by various stakeholders involved in it. Moreover, the disaster has been routinely occurring from time to time.

Mount Sinabung is one of the active Mount Merapi located in Karo Regency, North Sumatra Province. Since 2010 until 2015 Mount Sinabung had erupt routinely. Recorded since 2010, Mount Sinabung has experienced eruption in 2010, 2013, 2014, 2015 and 2017.

Disaster management has always considered not a priority and only comes at several times, even though we live in areas prone to the threat of natural disaster. Therefore, the understanding of disaster management needs to be understood and mastered by the government, society, and privates. Activities during this pre-disaster phase have been largely forgotten, but this is actually very important because what has been prepared at this phase is the principle in facing the disaster and post-disaster. It is rare for the government and both the society and private sector to think about what steps or activities need to be done in the event of a disaster or how to minimize the impact of a disaster. (Sukandarrumidi, 2011: 6566)

Various policies to reduce the risk of eruption of Mount Sinabung on mitigation efforts, preparedness, emergency response and recovery have been accommodated. (See Nugroho, 2006). Nevertheless, there are still many obstacles in both government and society in both the emergency and the recovery phases of the eruption. This condition is certainly different from the models of disaster management adopted in various countries with a systematic approach of pre-disaster. (Lestari et al, 2010)

In 2015, the Indonesian Government has established the Siosar region in Merek District in Karo Regency as a temporary shelter for the eruption refugees. There are 370 householders who have been evacuated to the region which is located 17 kilometers away from Kabanjahe. However, the problems in the mitigation policy are related to social and political issues. Social problems are linked to the psychological condition of the refugees who got relocated to Siosar. The political problem relating to disaster relocation policy to Siosar still leaves a polemic regarding the issue of home ownership and the fulfillment of refugee rights in Siosar. Based on the reason that this study departs from the empirical and theoretical background, the author would like to present a paper entitled Mitigation of Mount Sinabung Eruption Disaster: The SocioPolitical Impact of Refugee Relocation Policy in Siosar.

\section{RESEARCH METHODOLOGY}

This research uses qualitative method in which researcher collect data by in-depth interviews with sources who have capacity and capabilities related to disaster, environmental politics, government, NGOs and society. In determining the sources, researcher uses Purposive Sampling technique in which researcher determined the sources in accordance with the capacity and competence related to this research. Researcher also collects a variety of other qualitative data forms such as documents that are useful for the development of a deeper understanding of this research. 


\section{RESULTS AND DISCUSSION}

\section{A. Status of Shelter Ownership in Siosar}

The hope for the implementation of disaster management in Indonesia will soon to be realized is so big that the new institution is expected to be able to cope with every disasters in Indonesia. Although socialization and dissemination of informations related to disaster threats in Indonesia through various media continue to be voiced, but our awareness of it is still very minimal. (Haifani, 2006)

Understanding the paradigm of the threat of eruption of Mount Sinabung disaster really become a reality and will be quickly forgotten along with the passage of time and the loss of media coverage of Sinabung. The disaster shows that although this area has been receiving tremendous attention in preparing its citizens in the wake of the eruption hazard, at the time of the actual event there is still a fairly long panic.

The damages and devastation due to the volcanic ash of eruption of Mount Sinabung that is not taken into account. Regulation No. 24/2007 has mandated the need for an understanding of the characteristics of threats, the risks and the preparation of anticipatory plans for the eruption of Mount Sinabung, although this regulation is still relatively new, the socialization of regulations and technical guidelines has not reached the Karo Regency completely.

Basically, the refugee community strongly agrees if they are relocated from their home areas to the Siosar area as the destination. The underlying reasons for them agreeing with the relocation including their original location can no longer be occupied, the source of the livelihood is gone and the community is afraid of the threat.

However, the policy problem point faced by the relocation of refugees in Siosar is the problem of the ownership status of the houses they are living in. This is related to their occupancy status policy. Until now the status of their home ownership is still not clear. This happens because the refugee community who live in Siosar has not received legitimate land certificates from the government and the National Land Agency (Badan Pertanahan Nasional) related to the ownership documents. This certainly raises public concern about the clarity.

\section{B. Loss of Local Wisdom of Refugees}

The process of settlements by the government from evacuation to Siosar should be recognized as relatively slow. Construction of the new settlement has started from 2012 and the people of Suka Meriah Village have just been moved to Siosar by 2015. It is recorded that from September 2013 that the community is obliged to stay in the evacuation location. This shows that the community has been living in the shelter houses for quite some time. (Stenfri Loy Pandia, Rini Rachmawati and Estuning Tyas Wulan, 2016)

Furthermore, the victims of the eruption disaster relocated to Siosar are experiencing very complex conditions economically, physically, and socially. The main problem is the physical problems, such as disruption of the needs of clothing, food, health, and education as they have to work as well. These conditions originated from lack of availability or limited facilities in Siosar with a great distance. Moreover, the victims of the eruption relocated to Siosar have not been able to forget their loss caused them to become poor. Not only that, the source of daily livelihoods such as agricultural land is damaged.

The memory of losing family members affected by the Sinabung eruption, especially the source of family breadwinner, often causes anxiety, fear and even prolonged trauma. Assistance from various material-shaped sources in Siosar which may be able to meet the physical needs of disaster victims is not necessarily recognized to solve the problems in the wake of the devastation.

Refugees are experiencing another adversity faced with the psychological problems of society, such as fear of aftershocks and longing for earlier conditions as they once had. In addition, by being forced to live in temporary dwellings in Siosar that is not yet clear in status and also in a limited condition adds a sense of the eruption has not occurred.

The matter that worsens the condition of the people in the relocation is the people ignited conflicts with their fellow for various reasons. Unnecessary livelihoods and needs becomes such problem that they have to face everyday, ineffective implementation of family functions and social roles and the possibility of loss of self-control in shelter areas, the disappointment of the government often has the potential to infuriate them. Therefore, the land granted by the government to the refugee community in Siosar is barren with a calculation of half a hectare per family.

In accordance to citizens, Mrs. Hendra Br Sembiring said; "The gradually lost local wisdom that once have been in their village before being hit by an eruption, which was still compact, now starts to disappear because they have lived far apart from one shelter house to another house".

\section{Welfare of Refugees Still Far from Prosperity}

The relocated community in Siosar feels that aid funds in the form of land or house lease funds and life insurances are not sufficient to meet their daily needs. Their spending budget is greater than the grants provided by the government to the community. Funding for school assistance is only given for once; for high school students given 2 million, junior high school given 1.5 million and elementary school children given 1 million. Until then, there is no more aid funds to school children. As we know that funding for schools is quite high so to meet the needs of the community, they took the initiative to find another job to supplement their family income.

The average type of work undertaken by the community is to work in the fields owned by another person or their own siblings', regarding the livelihoods of most people in Suka Meriah Village are working as farmers. But not a few people are also looking for other jobs such as collecting used goods, dishwasher in rice stalls, and laundry service to meet their daily needs. The community feels that the government has not fulfilled the promise of granting aid. Relief funds from the government are considered inadequate to the public. Karo 
Regency guarantees life only smoothly in the first 3 months, starting from June 2014 when they declared out of refugee post, while the rest just given in May 2015 ago. (Stenfri Loy Pandia, Rini Rachmawati and Estuning Tyas Wulan, 2016).

One more problem that makes the people disappointed is when many unscrupulous people are selling refugees namesake to do fundraising. The reality is that the aid never reaches the people. People hope to anyone who wants to give help to give it directly into the hands of the community without having to go through a third-party because lots of fraud that happened. This would make the refugees who relocated to Siosar must work as laborers in the fields owned by the capital owners in the Karo Regency with a very low salary that sometimes can not meet the needs for their welfare.

\section{CONCLUSION}

The policy in relocating the Sinabung refugees to Siosar must take the social-political and social aspects of refugees into account in regard to mitigation. Furthermore, managing disasters in Mount Sinabung can not be done only by impromptu, but have to be planned in a good long-term management before a disaster could occur through a process called disaster management. The implementation of countermeasures must be a range of efforts which includes the determination of development policies that deal with emergence of disasters, intermediate disaster, emergency response, and rehabilitation. For that, in handling the eruption of Mount Sinabung it is required a certain level of seriousness.
Cooperation in handling the disaster management of Mount Sinabung would be useful to accelerate recovery so that its handling will be more effective and efficient in considerance of life expectancy and socio-political expectations. Of course, if mitigation is done by paying attention to these aspects, it should bring a quick anticipation in overcoming the existing problems. The problems that are always related to the big amounts of loss could be overcame with insurance in favor of the refugees.

\section{REFERENCES}

[1] Haifani, Akhmad Muktaf. 2006. Manajemen Resiko Bencana Gempa Bumi (Studi Kasus Gempa Bumi Yogyakarta 27 Mei 2006). The research was conducted by Akhmad Muktaf Haifani at Center for Assessment of System and Technology of Safety, Installation and Nuclear Material, Bapetan Jakarta.

[2] Lestari et al. 2010. Manajemen Komunikasi Bencana Gunung Sinabung 2010 Saat Tanggap Darurat. This research is from National Development University "Veteran" Yogyakarta.

[3] Loy, Stenfri Pandia, Rini Rachmawati and Estuning Tyas Wulan. 2016. Relokasi

[4] Permukiman Desa Suka Meriah Akibat Kejadian Erupsi Gunung Api Sinabung Kabupaten Karo, Jurnal Perencanaan Wilayah dan Kota (Journal of Regional and City Planning) vol. 27, no. 2, pp. 137-150, August 2016, pp.139-150.

[5] Nugroho, Riant. 2004. Kebijakan Publik: Formulasi, Implementasi dan Evaluasi. Jakarta: PT. Elex Media Komputindo.

[6] Sukandarrumidi. 2010. Bencana Alam dan Bencana Anturopogene. Yogyakarta: Penerbit Kanisius. 